GRASAS Y ACEITES 68 (1)

January-March 2017, e180

ISSN-L: 0017-3495

doi: http://dx.doi.org/10.3989/gya.0796161

\title{
Anti-inflammatory activity of two varieties of pumpkin seed oil in an adjuvant arthritis model in rats
}

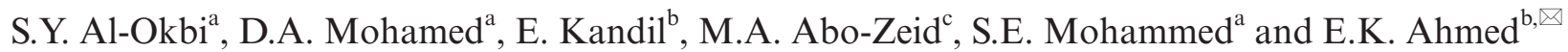 \\ ${ }^{a}$ Food Sciences and Nutrition Department, National Research Centre, Dokki, Cairo, Egypt \\ ${ }^{\mathrm{b}}$ Biochemistry Department, Faculty of Science, Ain Shams University, Cairo, Egypt \\ ${ }^{\circ}$ Genetics and Cytology Department, National Research Centre, Dokki, Cairo, Egypt \\ Corresponding author: emad.ahmed@sci.asu.edu.eg
}

Submitted: 13 July 2016; Accepted: 14 December 2016

SUMMARY: The aim of the present research was to evaluate the anti-inflammatory activity of pumpkin seed oils (PSOs) of an Egyptian and European variety, in a rat model of adjuvant arthritis. Edema thickness, plasma tumor necrosis factor- $\alpha(\mathrm{TNF}-\alpha)$ and erythrocyte sedimentation rate (ESR) were determined as inflammatory biomarkers while malondialdehyde (MDA) and total antioxidant capacity (TAC) were assessed as indicative of oxidative stress. Chromosomal aberration, sperm shape abnormalities, and DNA fragmentations are cytogenetic parameters which aid in tracing inflammatory and oxidative activity. Phenolic contents and $\beta$-carotene were determined in PSOs. The results showed elevated ESR, plasma TNF- $\alpha$, plasma MDA, liver cellular DNA fragmentation, bone marrow chromosomal aberration, sperm shape abnormalities with a reduction in plasma TAC and body weight gain in an adjuvant arthritis control compared to a healthy control. Administration of low and high doses of either Egyptian or European PSO improved all the aforementioned parameters with variable degrees.

KEYWORDS: Adjuvant arthritis; Anti-inflammatory; $\beta$-Carotene; Phenolic contents; Pumpkin seed oils

RESUMEN: Actividad antiinflamatoria de dos variedades de aceite de semillas de calabaza en un modelo de artritis adyuvante en ratas. El objetivo de la presente investigación fue evaluar la actividad antiinflamatoria de aceites de calabaza (PSOs) de variedades egipcia y europea, en un modelo de rata con artritis adyuvante. El espesor del edema, el factor de necrosis tumoral (TNF- $\alpha$ ) y la velocidad de sedimentación eritrocitaria (ESR) se determinaron como biomarcadores inflamatorios, mientras que el malondialdehído (MDA) y la capacidad antioxidante total (TAC) fueron evaluados como indicativos de estrés oxidativo. La aberración cromosómica, las anomalías de la forma del esperma y las fragmentaciones del ADN son parámetros citogenéticos que ayudan a localizar la actividad inflamatoria y oxidativa. Se determinaron contenidos fenólicos y $\beta$-caroteno en PSOs. Los resultados mostraron elevado ESR, TNF- $\alpha$ plasmático, MDA plasmática, fragmentación del ADN del hígado, aberración cromosómica de la médula ósea, anomalías de la forma espermática con una reducción del TAC plasmático y un aumento del peso corporal en el control de la artritis adyuvante en comparación con el control sano. La administración de dosis bajas y altas de PSO egipcia o europea mejoró todos los parámetros mencionados en grados variables.

PALABRAS CLAVE: Aceites de semillas de calabaza; Antiinflamatorio; Artritis adyuvante; $\beta$-Caroteno; Contenido fenólico

ORCID ID: Al-Okbi SY http://orcid.org/0000-0002-8114-2718, Mohamed DA http://orcid.org/0000-0003-0606-9378, Kandil E http://orcid.org/0000-0003-4731-7315 Abo-Zeid MA http://orcid.org/0000-0003-1566-6684 Mohammed SE http://orcid.org/0000-0003-3463-8945 Ahmed EK http://orcid.org/0000-0002-5511-1678

Citation/Cómo citar este artículo: Al-Okbi SY, Mohamed DA, Kandil E, Abo-Zeid MA, Mohammed SE, Ahmed EK. 2017. Anti-inflammatory activity of two varieties of pumpkin seed oil in an adjuvant arthritis model in rats. Grasas Aceites 68, e180. http://dx.doi.org/10.3989/gya.0796161

Copyright: (C) 2017 CSIC. This is an open-access article distributed under the terms of the Creative Commons Attribution (CC-by) Spain 3.0 License. 


\section{INTRODUCTION}

Oxidative stress and inflammation are the main causes of many chronic diseases including rheumatoid arthritis (RA). Oxidative stress plays an important role in the initiation and progression of joint diseases (Knight, 2000). Reactive oxygen species (ROS) cause oxidative damage which accumulates during the life cycle, the radical-related damage affects DNA, proteins and lipids which have been proposed to play a key role in the development of arthritis.

RA is an autoimmune disease that causes chronic inflammation of the joints and surrounding tissue with infiltration of macrophages and activated $T$ cells. The pathogenesis of this disease is predominantly linked with the formation of free radicals at the site of inflammation. The disease progression of RA is associated with chronic soft tissue inflammation, which is often followed by bone and cartilage destruction of inflamed joints (Anderson et al., 2012). Oxidative injury and inflammation is reflected in increased levels of serum TNF- $\alpha$ that has been shown to play a critical role in the onset and progression of RA. The overproduction of TNF- $\alpha$ could stimulate cartilage matrix degradation by inhibiting the production of proteoglycans and type II collagen and up-regulating the production of matrix-degrading enzymes (Goldring, 2000). An excessive accumulation of ROS may cause cellular oxidative damage to nucleic acids, proteins and chromosomal aberrations in the cells of several systems and that could occur in RA as reported previously (Al-Okbi et al., 2011).

The inverse association between fruit and vegetable intake and the risk of chronic diseases related to morbidity and mortality is often attributed to bioactive ingredients that may possess anti-inflammatory and antioxidant activity such as vitamins $\mathrm{C}$ and $\mathrm{E}$, carotenoids and polyphenols (Prakash and Gupta, 2009). Plant foods are rich sources of such bioactive ingredients. The pumpkin seed is among the plant foods that contain high levels of bioactive ingredients, including $\beta$-carotene, unsaturated fatty acids, phenolic compounds, phytosterols and tocopherols especially in the oil compartment. These functional food ingredients have been reported to possess both anti-inflammatory and antioxidant activities in hyper-cholesterolemic rats (Al-Okbi et al., 2014).

The aim of the present research was to assess the functional food ingredients, $\beta$-carotene and phenolic contents, in PSOs of the Egyptian and European varieties. The main objective was to evaluate the PSOs' anti-inflammatory activity and the related mechanism in a rat model of chronic inflammation that simulates RA in humans.

\section{MATERIALS AND METHODS}

\subsection{Plant materials}

Egyptian pumpkin seeds (Cucurbita moschata, L. Family Curcubitaceae) were purchased from the local market, Cairo, Egypt. A European PSO (Cucurbita pepo, L. Family Cucurbitaceae var. styria) was obtained from Graz, Austria.

\subsection{Animals}

Male white albino rats of $100-110 \mathrm{~g}$ body weight were used in the present study. The animals were kept individually in stainless steel cages; water and food were given ad-libitum. The animal experiment was carried out adopting the Ethics Committee of the National Research Centre, Cairo, Egypt, and followed the recommendations of the National Institutes of Health Guide for Care and Use of Laboratory Animals (Publication No. 85-23, revised 1985).

\subsection{Major chemicals}

Colchicine and Folin-Ciocalteu reagent were purchased from Sigma (USA) and Sigma-Aldrich, Germany, respectively. Freund's complete adjuvant (FCA) was supplemented from DIFCO LABORATORIES, Detroit, Michigan USA. All chemicals and solvents used were of high quality analytical grade.

\subsection{Preparation of PSO}

PSO was prepared from Egyptian pumpkin seeds by extraction using petroleum ether $\left(40-60^{\circ} \mathrm{C}\right)$ (Al-Okbi et al., 2014).

\subsection{Determination of total phenolic content (TPC) of the oils}

TPC was extracted from PSOs and determined colorimetrically using the Folin-Ciocalteu reagent (Singleton and Rossi, 1965). Absorbance was measured at $765 \mathrm{~nm}$ using a UVPC spectrophotometer. Gallic acid was used as a standard and results were calculated as mg gallic acid equivalent (GAE) per gm of oil. The reaction was conducted in triplicate and results were averaged.

\subsection{Assessment of $\beta$-carotene in Egyptian and European PSO}

$\beta$-Carotene was determined using the HPLC method (Hart and Scott, 1995). The exact weights of 2.5 grams from the Egyptian and European PSOs were weighed in two separate glass screw cap tubes. The oils were homogenized with $20 \mathrm{ml}$ ethanol (HPLC) by vortex mixing ( $5 \mathrm{~min}$ ), then 10 $\mathrm{ml}$ of hexane (HPLC) were added to each tube, 
mixed for $2 \mathrm{~min}$, centrifuged $(5 \mathrm{~min}, 5000 \mathrm{~g}$ ) and the clear upper layer was carefully transferred to other glass screw cap tubes. The samples were re-extracted twice with hexane. Then $7 \mathrm{ml}$ of the hexane extracts were dried to completion under a nitrogen stream and re-suspended in $1 \mathrm{ml}$ of $50 \%$ ethanol for analysis by the HPLC System. HPLC conditions: Waters Melinnium 3.2 software using a system equipped with a binary pump system (Waters 515), an auto-injector (Waters 717 plus), a PDA detector (Waters 996), and a column heater (Spectra Physics SP8792). The compound was separated on a $4.6 \times 250 \mathrm{~mm}, 5 \mu \mathrm{m}$, YMC Carotenoid column (C-30 reverse-phase) purchased from Waters (Milford, MA), which was maintained at $35{ }^{\circ} \mathrm{C}$. The following gradient system was used: methanol/water/triethylamine $(90: 10: 0.1 \mathrm{v} / \mathrm{v} / \mathrm{v})(\mathrm{A})$, and methanol/MTBE/triethylamine $(6: 90: 0.1 \mathrm{v} / \mathrm{v} / \mathrm{v})(\mathrm{B}) ;$ gradient $(\mathrm{min} / \% \mathrm{~A})$ $0 / 99,8 / 99,45 / 0,50 / 0$, and 53/99. The column was brought back to initial conditions, and allowed to equilibrate for 10 minutes before injection. All solvents were filtered and degassed before use. The concentration of $\beta$-carotene in the samples was obtained by comparing its peak area with the peak area of standard $\beta$-carotene in relation to concentration.

\subsection{Preparation of dosage form}

An emulsion of each oil was prepared using gum acacia to easily manage the rats' oral dose. The same concentration of gum acacia was prepared in water (the vehicle) to be given to control groups of rats.

\subsection{Preparation of diet}

A balanced diet was prepared containing 11.9 casein (10 protein), 10 sunflower oil, 45.73 corn starch, 22.87 sucrose, 5 cellulose, 1 vitamin mixture and 3.5 salt mixture as $\mathrm{g} . / 100 \mathrm{~g}$.

\subsection{In-vivo study of the anti-inflammatory activity of PSO in rats}

The potential anti-inflammatory effect of PSOs was evaluated in an adjuvant arthritis model (chronic inflammation model) of rats. Adjuvant arthritis (AA) was induced by subcutaneous injection of $0.3 \mathrm{ml} \mathrm{FCA} /$ rat into the sub-planter region of the right hind paw (Singh et al., 1992).

Thirty-six male albino rats were divided into 6 groups, 6 rats each; all rats were fed a normal balanced diet throughout the experiment. The rats from the first group (control normal) received no medication or injection and were given a daily oral dose of the vehicle for 21 days. Rats of the second group (adjuvant arthritis control) were given a daily oral dose of the vehicle for 21 days; the rats were treated with FCA 8 days from starting vehicle dosing. The rats of group 3 were given a daily oral dose of Egyptian PSO $(40 \mathrm{mg} / \mathrm{Kg}$ rat body weight) for 21 days along with treatment by FCA 8 days later from starting the oral dose. Rats of group 4 were given a daily oral dose of Egyptian PSO (500 $\mathrm{mg} / \mathrm{Kg}$ rat body weight) for 21 days while FCA was injected 8 days from starting the oral dose. The rats of groups 5 and 6 were treated like groups 3 and 4, respectively but with applying the European PSO. The food intake and body weight of rats were recorded once a week. At the end of the experiment, total food intake, body weight gain and food efficiency ratio were calculated. Paw thickness was measured immediately before the induction of arthritis (zero time) and at the end of the experiment using Vernier caliper to assess the degree of inflammation. The increase in the thickness of the injected paw (inflammation thickness) of the rats of all groups was calculated. Also, at the end of the experiment, rats were anesthetized and blood samples were withdrawn from the eye vein orbital after an overnight fast $(16 \mathrm{~h})$. Blood samples were divided into two parts. One was mixed with trisodium citrate (109 $\mathrm{mmol} / \mathrm{L}$ ) for the determination of the erythrocyte sedimentation rate (Westergren, 1921), the second part was mixed with heparin as anticoagulant, followed by centrifugation at $3000 \mathrm{rpm}$ for 15 min for separation of plasma and determination of TNF- $\alpha$ (Stepaniak et al., 1995), MDA (Satoh, 1978) and total antioxidant capacity (Koracevic et al., 2001). ESR and TNF- $\alpha$ are both considered as inflammatory biomarkers. Plasma MDA and total antioxidant capacity were assessed for evaluating the oxidative stress and/or antioxidant status.

All rats were kept alive for an additional 24 hours and treated by intraperitoneal injection of colchicine at a concentration of $3 \mathrm{mg} / \mathrm{kg}$ body weight. After 2 hours of injection, rats were anesthetized with ether and sacrificed; the liver was separated, washed with saline and received upon filter paper to remove any excess blood then wrapped with foil and kept at $-20^{\circ} \mathrm{C}$ until being analyzed for DNA fragmentation assay. The reproductive tract was exposed and the epididymus were excised. Both epididymus of each rat were received in a tube containing saline. The femurs bones of both legs of each rat were also received on saline in another tube. Both epididymus and the bone marrow of the femur were taken immediately for cytogenetic and chromosomal aberration tests.

For an extra cytogenetic study, two more groups were run parallel to the previous groups; each of 6 rats; a group was given daily oral dose of Egyptian PSO $(500 \mathrm{mg} / \mathrm{Kg}$ rat body weight) and the other group was given the same dose from the European variety for 21 days and fed on balanced diet. 


\subsection{Assessment of cytogenetic parameters}

\subsubsection{Chromosomal aberrations test}

Bone marrow metaphases were prepared (Yosida and Amano, 1965). Bone-marrow cells from both femurs were collected in a 6-8 $\mathrm{ml}$ hypotonic solution of $\mathrm{KCl}(0.075 \mathrm{M})$. The cell suspension was incubated for about $20 \mathrm{~min}$. at $37^{\circ} \mathrm{C}$ then centrifuged at $1000 \mathrm{rpm}$ for $10 \mathrm{~min}$. After discarding the supernatant, cells were fixed by re-suspending in freshly-prepared cold fixative methanol/ acetic acid (3:1), and centrifuged again for $10 \mathrm{~min}$. at $1000 \mathrm{rpm}$. The fixation step was repeated at least three times. Finally, the cells were re-suspended in the appropriate volume of fixative and were spread by dropping the concentrated cell suspensions onto slides that had just been removed from the freezer. Five to seven slides were prepared for each rat. The slides were stained with 7\% Giemsa in phosphate buffer ( $\mathrm{pH}$ 6.8). One hundred well-spread Metaphases were analyzed per animal. Different chromosome aberrations including gaps, breaks, fragments and deletions were recorded.

\subsubsection{Sperm shape abnormalities}

The protocol recommended previously (Wyrobek, 1978) was used. Both epididymus from each rat were minced together with small scissors in physiological saline, pipetted up and down and then filtered into small test tubes to exclude large tissue fragments to which the volume was made up to $2 \mathrm{ml}$. Smears were prepared on clean dry slides. The slides were stained in 1\% Eosin Y (aqueous). Six rats were taken for each treatment and at least three slides were prepared for each rat to study sperm abnormalities for microscopical examination. For each dose, at least 5000 sperms were assessed for morphological abnormalities of the sperm shape.

\subsubsection{DNA fragmentation assay}

The method of DNA fragmentation was carried out (Perandones et al., 1993). Reagents used were hypotonic lysis buffer $\mathrm{pH} \quad 8.0,10 \%$ Trichloroaceticacid (TCA), 5\% TCA and color reagent. Hypotonic lysis buffer was made from $0.2 \%$ Triton X-100, $10 \mathrm{mM}$ Tris and $1 \mathrm{mM}$ EDTA while the color reagent consisted of $0.088 \mathrm{M}$ Diphenylamine (DPA), 98\% v/v Glacial acetic acid, $1.5 \% \mathrm{v} / \mathrm{v}$ Sulphuric acid and $0.5 \% \mathrm{v} / \mathrm{v} 1.6 \%$ Acetaldehyde solution. The liver tissues $(50 \mathrm{mg})$ were mechanically dissociated in $400 \mu \mathrm{L}$ hypotonic lysis buffer to obtain cell lysate. The cell lysate was centrifuged at $13.800 \mathrm{xg}$ for 15 minutes. The supernatant containing small DNA fragments was separated immediately, the supernatant and the pellet containing large pieces of DNA, were used for the diphenylamine (DPA) assay.

\subsubsection{Diphenylamine assay (DPA)}

The colorimetric determination of DNA content was assessed (Perandones et al., 1993). Both the supernatant and the pellet were used for DPA assay after acid extraction of DNA. The pellet containing large fragments of DNA and cell debris was resuspended in a $400 \mu 1$ hypotonic lysis buffer. TCA $(10 \%)$ was added $(400 \mu \mathrm{l})$ to both the supernatant and the re-suspended pellet. The tubes were centrifuged at $2000 \mathrm{rpm}$ for $10 \mathrm{~min}$. The precipitate was re-suspended in $400 \mu \mathrm{l}$ of $5 \%$ TCA. The tubes were incubated at $80{ }^{\circ} \mathrm{C}$ for $30 \mathrm{~min}$. The supernatant containing the extracted DNA was left to cool at room temperature. Two volumes of the color reagent were added to one volume of extracted DNA. The samples were stored at $4{ }^{\circ} \mathrm{C}$ for $48 \mathrm{~h}$ till the blue color was developed. The blue color was measured colorimetrically using a spectrophotometer at $578 \mathrm{~nm}$. The percentage of DNA fragmentation in each sample was expressed by the formula: \% DNA fragmentation = OD of supernatant $\mathrm{x}$ 100/OD of supernatant + OD of pellet, where OD is the optical density.

\subsection{Statistical analysis}

Results of total phenolic content were expressed as mean $\pm S E$ with application of t-Students test. The results of the animal experiments were presented as the mean \pm SE and were analyzed statistically using one-way analysis of variance ANOVA followed by LSD test. In all cases $\mathrm{p}<0.05$ was used as the criterion for statistical significance. For the statistical analysis of chromosomal aberrations in bone marrow cells, the Chi-square test ( $X^{2}$ contingency table) was applied. One-way analysis of variance (ANOVA test) was applied to the data of sperm shape abnormalities and DNA fragmentation in liver cells.

\section{RESULTS}

\section{1. $\beta$-carotene and total phenolic contents of PSOs}

In Table 1, the European oil showed a higher $\beta$-carotene level compared with the Egyptian oil (28.5 and $17.9 \mu \mathrm{g} / 100 \mathrm{~g}$ oil, respectively). In addition,

TABLE 1. $\beta$-carotene and total phenolic content in PSOs

\begin{tabular}{|c|c|c|}
\hline Parameters & Egyptian PSO & European PSO \\
\hline$\beta$-carotene $(\mu \mathrm{g} / 100 \mathrm{~g}$ oil $)$ & 17.9 & 28.5 \\
\hline $\begin{array}{l}\text { Total phenolic }{ }^{\dagger} \text { (mg GAE/g } \\
\text { oil) }\end{array}$ & $1.71 \pm 0.012$ & $14 \pm 0.15^{*}$ \\
\hline
\end{tabular}

GAE: Gallic acid equivalent, ${ }^{\dagger}$ Total phenolic was calculated as mean \pm SE, "Phenolic contents of European oil was significantly higher than that of the Egyptian oil, ${ }^{*} P<0.001$. 
the studied oils showed the presence of total phenolic content at 1.71 and $14 \mathrm{mg}$ GAE/g in Egyptian and European oil, respectively. The total phenolic content of the European oil was significantly higher than that of the Egyptian variety.

\subsection{In-vivo study of the anti-inflammatory activity of PSOs in rats}

\subsubsection{Assessments of Inflammation}

The increase in foot thickness (thickness of inflammation) of the control arthritic rats at the end of the experiment compared with the rats given different oil treatments is shown in Table 2. Different doses of pumpkin oil produced a significant reduction in foot swelling compared to the arthritic control. Non-significant differences were observed between arthritic rats given different oil doses. Pumpkin oils exhibited a significant inhibition of inflammation ranging from $31 \%$ to $50 \%$.

TABLE 2. Inflammation thickness of the injected foot (after 13 days of adjuvant arthritis induction) of arthritic rats given different doses of PSO compared to the control arthritic group

\begin{tabular}{lcc}
\hline \multicolumn{1}{c}{ Groups } & $\begin{array}{c}\text { Inflammation thickness } \\
(\mathbf{c m})(\text { Mean } \pm \text { SE) }\end{array}$ & $\begin{array}{c}\text { \% Inhibition of } \\
\text { inflammation }\end{array}$ \\
\hline Arthritic control & $0.400^{\mathrm{a}} \pm 0.013$ & - \\
European high dose & $0.217^{\mathrm{b}} \pm 0.017$ & 46 \\
European low dose & $0.200^{\mathrm{b}} \pm 0.026$ & 50 \\
Egyptian high dose & $0.223^{\mathrm{b}} \pm 0.009$ & 44 \\
Egyptian low dose & $0.275^{\mathrm{b}} \pm 0.017$ & 31
\end{tabular}

In the same column different letters mean significant differences at 0.01 probability.

\subsubsection{Biochemical and nutritional parameters of arthritic rats}

The results of the biochemical changes in the different groups of rats in the adjuvant arthritis experiment are shown in Table 3. Plasma TNF- $\alpha$, MDA and ESR were significantly higher in arthritic rats than the normal control. The plasma level of total antioxidants was significantly lower in the arthritic rats compared to the normal control. Plasma TNF- $\alpha$, MDA and ESR showed significant reductions in arthritic rats given different pumpkin oil doses compared to the arthritic control. In addition; the plasma level of total antioxidants was significantly higher in the arthritic rats given different oil treatments compared to the arthritic control. Both Egyptian and European high pumpkin oil dose groups have comparable and significant plasma TNF- $\alpha$, ESR, MDA and total antioxidant levels. It is noted that high pumpkin oil doses have a much more potent effect rather than lower doses on reducing plasma TNF- $\alpha$. No significant change was noticed in ESR and plasma MDA among the different oil treatments and doses. Different oil treatments normalized Plasma MDA levels except for the high dose of the European PSO. The level of ESR only normalized upon the administration of the Egyptian low dose of PSO. The rats given a high dose of Egyptian and European PSO showed no significant change in plasma total antioxidants compared to the normal control. However, the different oil treatments and doses could not normalize the level of TNF- $\alpha$.

The results of the nutritional parameters of the different groups of rats in adjuvant arthritis experiment are shown in Table 4. Final body weight, body weight gain, total food intake, and Food efficiency ratio decreased significantly in the control arthritic rats compared to the normal control. Final body

TABLE 3. Levels of ESR, TNF- $\alpha$, total antioxidant, and malondialdehyde (MDA) in the different experimental groups

\begin{tabular}{|c|c|c|c|c|}
\hline Parameters & $\begin{array}{c}\text { ESR } \\
(\mathrm{mm} / \mathrm{h})\end{array}$ & $\begin{array}{l}\text { TNF- } \alpha \\
(\mathrm{pg} / \mathrm{ml}) \\
\end{array}$ & $\begin{array}{c}\text { Total antioxidant (nmol/ } \\
\mathrm{ml})\end{array}$ & $\begin{array}{c}\text { MDA } \\
(\mathrm{nmol} / \mathrm{ml})\end{array}$ \\
\hline Normal healthy control & $1.33^{\mathrm{c}} \pm 0.21$ & $20.22^{\mathrm{d}} \pm 0.59$ & $1.88^{\mathrm{a}} \pm 0.07$ & $2.12^{\mathrm{c}} \pm 0.21$ \\
\hline Arthritic control & $\begin{array}{l}4.83^{\mathrm{a}} \pm 0.31 \\
\left(263^{3} \%\right)\end{array}$ & $\begin{array}{c}34.52^{\mathrm{a}} \pm 0.80 \\
(71 \%)\end{array}$ & $\begin{array}{c}1.35^{\mathrm{d}} \pm 0.04 \\
(-28 \%)\end{array}$ & $\begin{array}{c}4.92^{\mathrm{a}} \pm 0.29 \\
(132 \%)\end{array}$ \\
\hline Egyptian high dose & $\begin{array}{c}2.33^{\mathrm{b}} \pm 0.33 \\
\left(-52^{\circ} \%\right)\end{array}$ & $\begin{array}{c}23.72^{\mathrm{c}} \pm 0.43 \\
(-31 \%)\end{array}$ & $\begin{array}{c}1.70^{\mathrm{abc}} \pm 0.10 \\
(26 \%)\end{array}$ & $\begin{array}{c}2.70^{\mathrm{bc}} \pm 0.22 \\
(-45 \%)\end{array}$ \\
\hline Egyptian low dose & $\begin{array}{c}2.00^{\mathrm{bc}} \pm 0.26 \\
(-59 \%)\end{array}$ & $\begin{array}{l}28.17^{\mathrm{b}} \pm 0.79 \\
(-18 \%)\end{array}$ & $\begin{array}{c}1.55^{\mathrm{c}} \pm 0.04 \\
(15 \%)\end{array}$ & $\begin{array}{c}2.65^{\mathrm{bc}} \pm 0.23 \\
(-4 \overline{6} \%)\end{array}$ \\
\hline European high dose & $\begin{array}{l}2.50^{b} \pm 0.43 \\
(-48 \%)\end{array}$ & $\begin{array}{l}24.07^{\mathrm{c}} \pm 0.58 \\
(-30 \%)\end{array}$ & $\begin{array}{c}1.77^{\mathrm{ab}} \pm 0.08 \\
(31 \%)\end{array}$ & $\begin{array}{c}3.07^{\mathrm{b}} \pm 0.24 \\
(-38 \%)\end{array}$ \\
\hline European low dose & $\begin{array}{c}2.50^{\mathrm{b}} \pm 0.22 \\
(-48 \%)\end{array}$ & $\begin{array}{c}27.47^{\mathrm{b}} \pm 0.78 \\
(-20 \%)\end{array}$ & $\begin{array}{c}1.58^{\mathrm{bc}} \pm 0.06 \\
(17 \%)\end{array}$ & $\begin{array}{c}2.58^{\mathrm{bc}} \pm 0.10 \\
(-47 \%)\end{array}$ \\
\hline
\end{tabular}

Results are expressed as mean \pm SE of 6 rats.

In each column the same letter means non-significant difference while different letters mean significant differences at 0.05 probability. $\%$ change in the row of arthritic control was calculated by comparing arthritic control with normal control. \% change in the last 4 rows was calculated by comparing the arthritic groups given PSO with the arthritic control. 
weight and body weight gain increased significantly upon the administration of different PSO types and doses compared to the arthritic control. The final body weight and body weight gain of these treatments matched the normal control except for the high dose of the European variety. Compared to the arthritic control, the food efficiency ratio increased significantly upon administration of different PSO types and doses till it matched that of the normal control rats. No significant difference in total food intake was noticed between the groups given the European PSO and the arthritic control. Compared to the arthritic control, total food intake increased significantly upon administration of either doses of the Egyptian PSO variety till matching the normal control.

\subsubsection{Cytogenetic parameters in adjuvant arthritic rats}

\subsubsection{Chromosomal aberrations}

Rat bone marrow cells were collected from the rats of normal control, adjuvant arthritic control and from normal rats given high doses of either
European or Egyptian PSO. The results showed no significant chromosomal aberrations after treating normal animals with high doses of Egyptian or European PSO alone compared to the normal control. Adjuvant arthritic rats showed an induced genotoxicity in rat bone marrow cells represented by chromosomal aberrations. It was noticed that chromosomal aberrations including and excluding gaps increased significantly after treatment with FCA $(\mathrm{p}<0.05)$ compared to the normal rats (Table 5). Different types of chromosomal aberrations were observed (gaps, breaks, fragments and deletion) after treating animals with FCA (Table 5 and Figure 1).

The Egyptian and European PSO significantly reduced the percentages of chromosomal aberrations produced by FCA in comparison to rats of the adjuvant arthritic control group except for the Egyptian PSO low dose. The low dose of Egyptian PSO only reduced chromosomal aberrations including and excluding gaps without any significance. The percentages of inhibition after treating FCA rats with Egyptian PSO reached 20.75\% and 49.06\%

TABLE 4. Nutritional parameters of different experimental groups

\begin{tabular}{lccccc}
\hline Parameters & Initial body weight $(\mathrm{g})$ & Final body weight $(\mathrm{g})$ & Body weight gain $(\mathrm{g})$ & Total food intake $(\mathrm{g})$ & Food efficiency ratio \\
\hline $\begin{array}{l}\text { Normal healthy } \\
\text { control }\end{array}$ & $107.3^{\mathrm{a}} \pm 0.61$ & $167.5^{\mathrm{a}} \pm 2.39$ & $60.2^{\mathrm{a}} \pm 2.56$ & $259.0^{\mathrm{a}} \pm 7.32$ & $0.234^{\mathrm{ab}} \pm 0.01$ \\
Arthritic control & $107.7^{\mathrm{a}} \pm 2.27$ & $142.7^{\mathrm{c}} \pm 3.04$ & $35.0^{\mathrm{c}} \pm 3.29$ & $217.2^{\mathrm{b}} \pm 12.94$ & $0.164^{\mathrm{c}} \pm 0.01$ \\
Egyptian high dose & $107.3^{\mathrm{a}} \pm 2.72$ & $167.8^{\mathrm{a}} \pm 2.77$ & $60.5^{\mathrm{a}} \pm 1.43$ & $261^{\mathrm{a}} \pm 5.17$ & $0.232^{\mathrm{ab}} \pm 0.008$ \\
Egyptian low dose & $107.7^{\mathrm{a}} \pm 1.76$ & $163.2^{\mathrm{a}} \pm 3.88$ & $55.5^{\mathrm{a}} \pm 2.80$ & $256.7^{\mathrm{a}} \pm 7.48$ & $0.216^{\mathrm{b}} \pm 0.01$ \\
European high dose & $107.3^{\mathrm{a}} \pm 2.90$ & $152.3^{\mathrm{b}} \pm 3.37$ & $45^{\mathrm{b}} \pm 1.75$ & $216.8^{\mathrm{b}} \pm 2.16$ & $0.208^{\mathrm{b}} \pm 0.01$ \\
European low dose & $107.3^{\mathrm{a}} \pm 1.74$ & $164.0^{\mathrm{a}} \pm 3.05$ & $56.7^{\mathrm{a}} \pm 2.29$ & $223^{\mathrm{b}} \pm 6.50$ & $0.254^{\mathrm{a}} \pm 0.005$
\end{tabular}

Results are expressed as mean \pm SE of 6 rats.

In each column the same letter means non-significant difference while different letters mean significant differences at 0.05 probability.

TABLE 5. Number and mean percentages of chromosomal aberrations in rat bone-marrow cells of all experimental groups of the adjuvant arthritis experiment

\begin{tabular}{|c|c|c|c|c|c|c|c|c|c|c|}
\hline \multirow[b]{2}{*}{ Treatments } & \multicolumn{3}{|c|}{ Ch. Ab. Including Gaps } & \multicolumn{3}{|c|}{ Ch. Ab. Excluding Gaps } & \multicolumn{4}{|c|}{ Different types of Ch. Ab. } \\
\hline & No. & $\%$ & Inhibition \% & No. & $\%$ & Inhibition \% & G. & Br. & Fr. & Del. \\
\hline $\mathbf{C N}$ & 32 & 6.4 & - & 19 & 3.8 & - & 13 & 11 & 3 & 5 \\
\hline N Egp HD & 34 (ns) & 6.8 & - & $22(\mathrm{~ns})$ & 4.4 & - & 12 & 11 & 8 & 3 \\
\hline N Eur HD & 36 (ns) & 7.2 & - & $21(\mathrm{~ns})$ & 4.2 & - & 15 & 10 & 9 & 2 \\
\hline Ad.Arth. C & $53^{*}$ & 10.6 & - & $34^{*}$ & 6.8 & - & 19 & 14 & 11 & 9 \\
\hline Ad.Arth. + Egp LD & 42 & 8.4 & 20.75 & 25 & 5 & 26.47 & 17 & 16 & 6 & 3 \\
\hline Ad.Arth. + Egp HD & $27^{++}$ & 5.4 & 49.06 & $17^{+}$ & 3.4 & 50.00 & 10 & 7 & 8 & 2 \\
\hline Ad.Arth. + Eur LD & $29^{++}$ & 5.8 & 45.28 & $16^{+}$ & 3.2 & 52.94 & 13 & 9 & 5 & 2 \\
\hline Ad.Arth. + Eur HD & $25^{++}$ & 5.0 & 52.83 & $14^{++}$ & 2.8 & 58.82 & 11 & 10 & 3 & 1 \\
\hline
\end{tabular}

Total number of scored metaphases 500 (100 metaphases/ animal). Ch. Ab.:Chromosomal aberration; No: Numbers; G.:Gap; Br.: Break; Fr.: Fragment; Del.: Deletion. CN: control normal, Egp LD: Egyptian PSO low dose, N Egp HD: Normal rats treated with Egyptian PSO high dose, Eur LD: European PSO low dose, N Eur HD: Normal rats treated with European PSO high dose, Ad.Arth. C: Rats of control adjuvant arthritic group; Ad.Arth.: Rats with adjuvant arthritis

*: Significant compared to normal control $(\mathrm{p}<0.05)$; ns: Insignificant compared to normal control; ${ }^{+\&+}$ : Significant in comparison to adjuvant arthritis control $\left(+\mathrm{p}<0.05 ;{ }^{++} \mathrm{p}<0.01\right)$. 
in including gaps and $26.47 \%$ and $50 \%$ in excluding gaps for low and high doses, respectively (Table 5). Both low and high doses of European PSO given with FCA injection reduced chromosomal aberrations including and excluding gaps significantly in comparison to rats treated with FCA alone. The percentages of inhibition after treating animals with FCA and European PSO reached $45.28 \%$ and

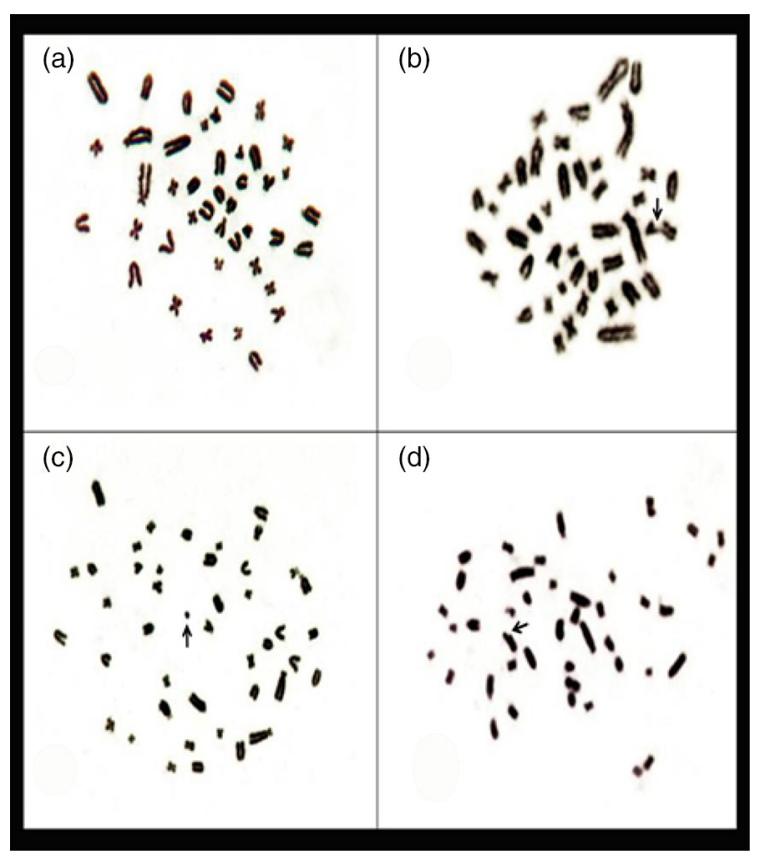

Figure 1. Metaphases with different chromosome aberrations in rat bone marrow cells after treatments with arthritic adjuvant for 13 days, (a) normal metaphase, (b) chromatid break, (c) fragment, (d) deletion. (X1250).
$52.83 \%$ in including gaps and $52.94 \%$ and $58.82 \%$ in excluding gaps for low and high doses, respectively (Table 5).

\subsubsection{Sperm shape abnormalities}

Sperm shape abnormalities are usually taken as a characteristic criterion and as an applied test for monitoring the mutagenic potential for many diseases or chemicals. In this experimental study, rat sperm cells were collected from normal healthy rats, normal rats given high doses of Egyptian or European PSO, rats treated with FCA alone or in combination with high or low doses of either Egyptian or European PSO to investigate their protective efficacy. The results showed that the treatment of normal rats with Egyptian and European PSO did not induce sperm shape abnormalities in comparison to the non-treated normal control. However, control adjuvant arthritic rats showed significant sperm shape abnormalities in comparison to non-treated rats. The percentage of sperm shape abnormalities (Table 6) was $2.8 \%(p<0.001)$ after treatment with FCA in comparison to control normal rats $(0.48 \%)$. The main types of sperm shape abnormalities observed were amorphous, triangular, banana shape, without hook and small head (Figure 2). Both Egyptian and European PSO reduced the percentages of sperm shape abnormalities produced by FCA highly significantly $(\mathrm{p}<0.001)$ in comparison to adjuvant arthritic control rats. The percentages of inhibition gradually increased with increasing doses of PSO. The percentages of inhibition reached $32.14 \%$ and $35.36 \%$ with low and high doses of Egyptian PSO, respectively. The inhibition percentage was $37.5 \%$ and

TABLE 6. Number and mean percentages of sperm shape abnormalities in rat sperms of the experimental groups of adjuvant arthritis experiment.

\begin{tabular}{|c|c|c|c|c|c|c|c|c|c|}
\hline \multirow[b]{2}{*}{ Treatments } & \multirow{2}{*}{$\begin{array}{l}\text { No. of } \\
\text { scored } \\
\text { sperms }\end{array}$} & \multicolumn{3}{|c|}{ Abnormal sperms } & \multicolumn{5}{|c|}{ Different types of sperm shape abnormalities } \\
\hline & & No. & Mean (\%) \pm SD & Inhibition \% & Amorphous & Triangular & Banana shape & $\begin{array}{c}\text { Without } \\
\text { hook }\end{array}$ & $\begin{array}{l}\text { Small } \\
\text { Head }\end{array}$ \\
\hline $\mathbf{C N}$ & 5024 & 24 & $0.48 \pm 0.13$ & - & 10 & 1 & 4 & 7 & 2 \\
\hline N EgpHD & 5029 & 29 & $0.58 \pm 0.21(\mathrm{~ns})$ & - & 10 & 0 & 0 & 16 & 3 \\
\hline N Eur HD & 5028 & 28 & $0.56 \pm 0.19$ (ns) & - & 11 & 1 & 2 & 13 & 1 \\
\hline Ad.Arth.C & 5144 & 144 & $2.80 \pm 0.14^{\mathrm{a}}$ & - & 58 & 15 & 15 & 48 & 8 \\
\hline Ad.Arth. + Egp LD & 5097 & 97 & $1.90 \pm 0.35^{\mathrm{b}}$ & 32.14 & 33 & 9 & 19 & 34 & 2 \\
\hline Ad.Arth. + Egp HD & 5092 & 92 & $1.81 \pm 0.29^{\mathrm{b}}$ & 35.36 & 25 & 13 & 22 & 32 & 0 \\
\hline Ad.Arth. + EurLD & 5089 & 89 & $1.75 \pm 0.25^{\mathrm{b}}$ & 37.50 & 24 & 11 & 24 & 28 & 2 \\
\hline Ad.Arth. + EurHD & 5084 & 84 & $1.65 \pm 0.13^{\mathrm{b}}$ & 41.07 & 18 & 5 & 28 & 31 & 2 \\
\hline
\end{tabular}

No: Numbers, CN: control normal, Egp LD: Egyptian PSO low dose, N Egp HD: Normal rats treated with Egyptian PSO high dose, Eur LD: European PSO low dose, N Eur HD: Normal rats treated with European PSO high dose, Ad.Arth. C: Rats of control adjuvant arthritic group, Ad.Arth.: Rats with adjuvant arthritis.

At least 1000 sperms/animal were scored (6 rats/group).

${ }^{a}$ Significance in comparison to non-treated rats (control normal) $(\mathrm{p}<0.001)$, (ns): Insignificant compared to normal control;

${ }^{\mathrm{b}}$ Significance in comparison to adjuvant arthritis control $(\mathrm{p}<0.001)$. 
$41.07 \%$ after treatment with low and high doses of European PSO, respectively (Table 6). These results indicated that European oil is slightly more effective than Egyptian oil.

\subsubsection{DNA fragmentation assay}

The liver cells were collected from all experimental animals and the percentages of DNA fragmentation were recorded. Both Egyptian and European oil did not induce DNA damage in the liver cells of normal healthy rats in comparison to non-treated animals (normal control). The percentages of DNA fragmentation were highly significant $(5.86 \% ; \mathrm{p}<0.001)$ in animals treated with FCA (adjuvant arthritic control) in comparison to the normal healthy control (3.4\%) (Table 7). Both Egyptian and European pumpkin oils reduced the DNA fragmentation induced by FCA. The reduction percentages were highly significant $(p<0.001)$ in comparison to animals treated with FCA alone. The percentages of inhibition were $30.92 \%$ and $37.52 \%$ after treatment with low and high doses of Egyptian oil, respectively. The inhibition percentages of DNA fragmentation were $36.04 \%$ and
$44.21 \%$ upon treatment with low and high doses of European oil, respectively (Table 7) which indicated a dose-dependent effect.

\section{DISCUSSION}

In the present research, the anti-inflammatory activity of two varieties of PSO, an Egyptian and a European, was studied in a chronic inflammatory model of adjuvant arthritis in rats. These types of oils were selected as they are expected to be rich in bioactive ingredients which could have antioxidant, free radical scavenging capacity and antiinflammatory effects.

In the present study, the induction of AA in rats produced high oxidative stress reflected in elevated plasma MDA and reduced total antioxidant capacity. Also inflammatory biomarkers represented by ESR and plasma TNF- $\alpha$ were significantly elevated in AA rats with the induction of foot paw inflammation. In support of the present work, arthritis is described as being a condition that involves systemic oxidative stress (Strosova et al., 1995). In previous studies, it was shown that plasma oxidative stress and inflammatory biomarkers increased in both AA (a)

(d)
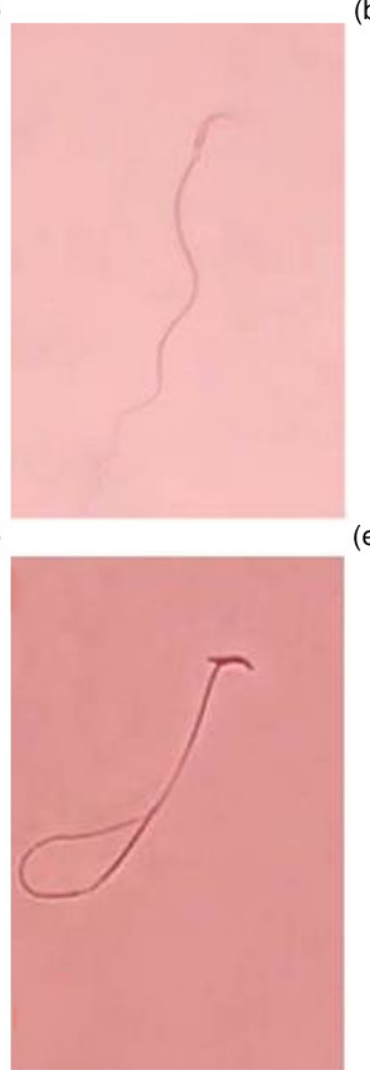

(b)

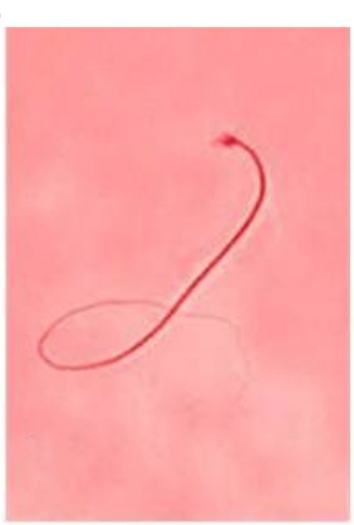

(e)

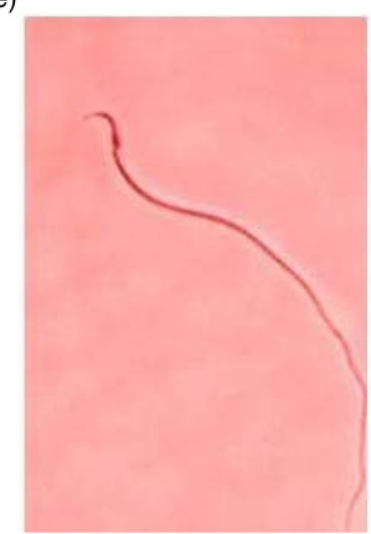

(c)

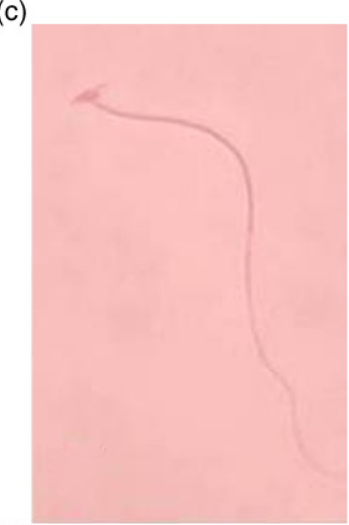

(f)

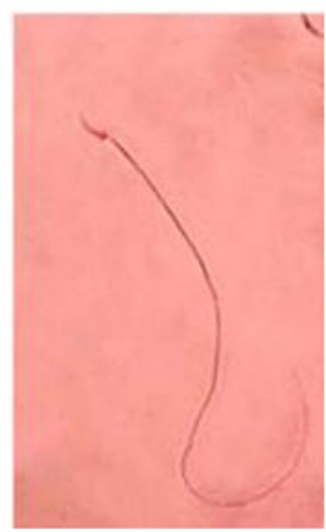

FIGURE 2. (a)- Normal sperm with a definite head and a marked hook from a control rat. (b-f) Different types of sperm shape abnormalities in rats treated with Freund's complete Adjuvant; (b) amorphous head; (c) triangular head; (d) without hook; (e) banana shape; (f) small head. (X1250). 
TABLE 7. Mean percentage of DNA fragmentation induced in rat liver cells injected with FCA with or without daily oral doses of Egyptian or European pumpkin oil (40 and $500 \mathrm{mg} / \mathrm{kg} \mathrm{b.} \mathrm{wt.)}$

\begin{tabular}{lcc}
\hline Treatments & $\begin{array}{c}\text { DNA } \\
\text { fragmentation } \\
\text { Mean (\%) } \pm \text { SD }\end{array}$ & Inhibition \% \\
\hline CN & $3.40 \pm 0.26$ & - \\
N Egp HD & $3.15 \pm 0.51$ & - \\
N Eur HD & $3.90 \pm 0.69$ & - \\
Ad.Arth.C & $5.86 \pm 0.74^{\mathrm{a}}$ & - \\
Ad.Arth. + Egp LD & $4.04 \pm 0.90^{\mathrm{b}}$ & 30.92 \\
Ad.Arth. + Egp HD & $3.66 \pm 0.18^{\mathrm{b}}$ & 37.52 \\
Ad.Arth. + Eur LD & $3.74 \pm 0.78^{\mathrm{b}}$ & 36.04 \\
Ad.Arth. + Eur HD & $3.27 \pm 0.28^{\mathrm{b}}$ & 44.21 \\
\hline
\end{tabular}

CN: normal control, Egp LD: Egyptian PSO low dose, N Egp HD: Normal rats treated with Egyptian PSO high dose, Eur LD: European PSO low dose, N Eur HD: Normal rats treated with European PSO high dose, Ad.Arth. C: Rats of control adjuvant arthritic group, Ad.Arth.: Rats with adjuvant arthritis (6 animals / group were investigated).

Significance in comparison to normal control $(p<0.001)$; b Significance in comparison to adjuvant arthritis control $(\mathrm{p}<0.001)$.

rats and in patients with RA (Al-Okbi et al., 2000a; 2000b; 2011; Stepaniak et al., 1995).

TNF- $\alpha$ is a potent pro-inflammatory cytokine that plays an important role in inflammation. It binds to its cellular receptor TNF receptor 1 , which triggers signaling cascades that activate $\mathrm{NF}-\kappa \mathrm{B}$ and activator protein 1 transcription factors. Proinflammatory cytokines like IL-1 $\beta$ and TNF- $\alpha$ could thus help to propagate the extension of a local or systemic inflammatory process by activating $\mathrm{NF}-\kappa \mathrm{B}$, forming a positive feedback mechanism which exaggerates the inflammatory process (Sonis, 2002).

Overproduction of lipid peroxide oxidative stress marker, MDA, was noticed in AA rats (Zhang et al., 2014). AA was monitored by hind paw volume and high level of MDA. During inflammatory joint diseases, like adjuvant-induced arthritis, phagocytes accumulate in the joints and produce superoxide and hydroxyl radicals as well as hydrogen peroxide. Such reactive oxygen species might contribute to the elevated ESR, plasma MDA, and TNF- $\alpha$ observed in the arthritic model of inflammation. An elevation of the oxidative damage marker such as blood MDA with reduction in total antioxidants in the present study demonstrated a disturbance in the oxidant to antioxidant balance in favor of lipid peroxidation, which could lead to the tissue damage seen in the disease. These results suggest the importance of therapeutic co-administration of antioxidants with conventional drugs in such condition.
Paw swelling, body weight loss and overproduction of serum TNF- $\alpha$ and MDA were reported as the main pathological signs in FCA-induced arthritis in rats (Zhang et al., 2014). Paw volume and ESR were evaluated as arthritic markers (Banji et al., 2014). During arthritis, TNF- $\alpha$ has been implicated in the pathological mechanisms of synovial tissue proliferation, joint destruction and apoptosis. Hemshekhar et al. (2013) demonstrated a significant reduction in arthritis-induced paw swelling and body weight regain, establishing a close relationship between inflammation and loss of body weight. $\mathrm{TNF}-\alpha$ played a role in the increased prevalence of low body mass which has been reported in arthritic individuals (Kaufmann et al., 2003). The decrease in body weight gain and food efficiency ratio in the control AA rats in the present study is similar to that in rheumatoid arthritis patients where the loss of lean tissues could be due to tissue destruction. Elevated TNF- $\alpha$ in arthritis could contribute in cartilage and bone degeneration through the activation of extracellular matrix degrading enzymes. The increase in TNF- $\alpha$ in the present study could thus explain the loss in weight gain. The enhanced degradation of muscle protein and muscle wasting in experimental arthritis might have a hand in body weight reduction. The decrease in total food intake in adjuvant arthritis rats in the current study is similar to the observed anorexia in RA patients and could participate in reducing body weight gain.

The administration of both PSOs to arthritic rats in the present study produced significant improvements in inflammatory and oxidative stress biomarkers together with a reduction in inflammation thickness. These effects are certainly attributed to the presence of antioxidant and anti-inflammatory constituents such as tocopherols, carotenoids, phytosterols, and phenolic compounds in the POs. The variation in degree of improvements may be related to the different contents and concentration of bioactive constituents and their synergistic effects. The present study showed the presence of phenolic compounds and beta- carotene in both varieties of PSOs. Also, the two varieties of PSOs were reported previously to contain phytosterols, unsaturated fatty acids, and tocopherols (Al-Okbi et al., 2014). These ingredients could collectively render the oils their antioxidant and anti-inflammatory activity.

Egyptian and European PSOs significantly inhibited the elevated plasma levels of TNF- $\alpha$ and MDA, thereby reducing the severity of inflammation as noticed from the reduced paw inflammation thickness. Eventually, elevated ROS promotes liver damage by elevating the levels of lipid peroxides. Lipid peroxides, represented in the present study by MDA, could behave as a secondary toxic trigger causing further damage by modulating membrane fluidity, permeability and transport in arthritic patients. Thus the level of MDA may be a sensitive marker 
of oxidative damage during arthritis and treatment with PSO which reflects the potent antioxidant and free radical scavenging activity of PSO.

PSOs have a significant inhibitory effect on foot inflammation and this ability to reduce edema may be related to its inhibitory action on TNF- $\alpha$ and ESR which reflect their anti-inflammatory activity. Also both Egyptian and European PSO doses significantly elevate the antioxidant capacity and thus they may play an important role in reducing the oxidative stress associated with the arthritic condition, and therefore has the potential to be used as an antiarthritic agent.

It was noticed that all treatments produced a significant increase in body weight gain and food efficiency ratio which is reflected in the improvement of AA condition.

The presence of $\alpha, \delta$ and $\gamma$-tocopherol in PSO (Al-Okbi et al., 2014) could have a significant impact on improving the changes in AA rats. The phenolic content and the considerable concentration from both tocopherol and $\beta$-carotene in PSO may explain the antioxidant and anti-inflammatory effects. The presence of a high phenolic content was reported to play an anti-arthritic role through lowering ESR and restoring body weight (Gupta et al., 2014).

Antioxidants play an important role in relieving arthritis in rats (Zhang et al., 2014). Chronic administration of PSO in the present study caused a remarkable elevation of serum antioxidant levels and a marked inhibition of paw edema that could be attributed to its high content of the aforementioned antioxidants.

PSO administration improved biochemical parameters studied in the present research during chronic arthritis which could be ascribed to the high level of unsaturated fatty acids in PSO and other antioxidants. Previously, extra-virgin olive oil was reported to reduce inflammation and cartilage-matrix degradation in a mice model of arthritis which was assigned to the adequate fatty acid profile and the presence of high phenolic content in the oil (Rosillo et al., 2016). Similarly, evening primrose oil could reduce the pro-inflammatory mediators in a model of fibromyalgia syndrome in mice (Montserrat-de la Paz et al., 2013) and in RA patients (Al-Okbi et al., 2000a) which might most probably be due to the presence of polyunsaturated fatty acids particularly gamma- linolenic acid. In another study, functional foods containing either fish oil or primrose oil showed beneficial effects in a rat model of arthritis due to their high levels of polyunsaturated fatty acids (Al-Okbi et al., 2012).

The present study indicated that AA has a highly significant genotoxic effect on rat bone marrow cells as well as sperm and liver DNA. Our results are in agreement with a previous study which reported the induction of structural and numerical aberrations in the synovial fibroblasts in RA patients and other inflammatory joint diseases (Wyllie et al., 1980). The current work also indicated DNA fragmentation induced by AA in rat liver cells similar to the work of Wyllie et al. (1980).

Oxidative metabolism is considerably enhanced in the liver of AA rats. The livers of adjuvant-induced arthritis rats show a pronounced high oxidative stress which is the consequence of both a stimulated pro-oxidant system and reduction in antioxidant defense represented by the lowering in catalase and glutathione peroxidase activities (Kelmer-Bracht et al., 2003). This liver high oxidative stress could be the cause of the observed DNA damage in the AA rats in the present study. The mRNA levels of mdrla and mdrlb encoding P-glycoprotein (P-gp) decreased significantly in the livers of the AA rats (Kawase et al., 2014). In arthritic rats, it was observed previously that there was a significant elevation in DNA damage and genotoxicity (Al-Okbi et al., 2011). Mutation rates might be increased due to the elevated level of DNA damage in adjuvant arthritis. The present study showed the protective role of the tested PSOs by inhibiting the genotoxic effects induced by adjuvant arthritis and the protection of cells against oxidative DNA damage. The bioactivity of PO could be attributed to the presence of the aforementioned bioactive constituents that could impart antioxidant and anti-inflammatory activity.

It was reported that carotenoids reduced the induction of micronuclei in polychromatic erythrocytes in mice bone-marrow cells (Rauscher et al., 1998). The protective effect of nut oil was demonstrated against free radical capacity due to the presence of tocopherols. Tocopherol itself was shown previously to possess protective effects against the induced genotoxicity in mice bone-marrow cells (Arranz et al., 2008). So tocopherols in combination with the different functional ingredients of PSO in the present study could have synergistic anti-genotoxicity. In the current research, the mutagenic effect and DNA fragmentation in AA was minimized by the oral administration of POs which significantly inhibited the sperm shape abnormalities, DNA fragmentation and chromosomal aberrations of somatic and germ cells. Total phenolics have been reported to have anti-mutagenic effects (Batista et al., 2016), so the phenolic content of PSO could have a similar effect.

The essential fatty acid, linoleic acid accounts for nearly one-third of the total fatty acid in pumpkin seeds while the contribution of $\alpha$-linolenic acid was considerably low (Glew et al., 2006; Tsaknis et al., 1997). These fatty acids could participate in the bioactivity of PSO.

Mini Paulista and Nova Caravela pumpkin varieties showed high amounts of total phenolic compounds in the lipid fractions and in the seeds. It was also found that $\gamma$-tocopherol is the isomer that stood out in the lipid fractions and in the seeds, mainly in Menina Brasileira (Veronezi and Jorge, 2012). 


\section{CONCLUSIONS}

The present study showed that both the Egyptian and European varieties of PSO improved the biochemical and nutritional changes in an adjuvant arthritis model and reduced the genotoxicity and paw inflammation which nominate PSO as being a protective agent towards RA or complementary to therapy used for this disease. The bioactivity of PSO might be ascribed to its contents of total phenolics and beta-carotene determined in the present study, in addition to phytosterols, unsaturated fatty acids and tocopherols, as reported previously.

\section{ACKNOWLEDGMENTS}

This work was completely financed by the National Research Centre Cairo, Egypt.

\section{REFERENCES}

Al-Okbi SY, Ammar NM, Soroor KhA, Mohammed DA. 2000a. Impact of natural oils supplements on disease activity and antioxidant state of Egyptian patients with rheumatiod arthritis. Med. J. Islamic Acad. Sci. 13, 161-171.

Al-Okbi SY, Sorour Kh, Abdel-Samed AM, Rashed MM, Mohamed DA. 2000b. Nutritional status and blood antioxidant levels of Egyptian rheumatoid arthritis patients. Kasr El Aini Med. J. 6, 43-64.

Al-Okbi SY, Mohamed DA, Donya SM, Abd El Khalek AB. 2011. Role of Bifidobacterium bifidum and Plant Food Extracts in Improving Microflora and Biochemical and Cytogenetic Parameters in Adjuvant Arthritis. Grasas Aceites 62, 308-320. http://dx.doi.org/10.3989/ gya. 089810

Al-Okbi SY, Mohamed DA. 2012. Preparation and evaluation of functional foods in adjuvant arthritis. Grasas Aceites 63, 394 402. http://dx.doi.org/10.3989/gya.130811

Al-Okbi SY, Mohamed DA, Kandil E, Ahmed EK, Mohammed SE. 2014. Functional ingredients and cardiovascular protective effect of pumpkin seed oils. Grasas Aceites 65, e007. http://dx.doi.org/10.3989/gya.062813

Anderson J, Caplan L, Yazdany J, Robbins ML, Neogi T, Michaud K, Saag KG, O’Dell JR, Kazi S. 2012. Rheumatoid arthritis disease activity measures: American College of Rheumatology recommendations for use in clinical practice. Arthritis Care Res. 64, 640-647. http:// dx.doi.org/10.1002/acr.21649

Arranz S, Cert R, Pérez-Jiménez J, Cert A, Saura-Calixto F. 2008. Comparison between free radical scavenging capacity and oxidative stability of nut oils. Food Chem. 15, 985-990. http://dx.doi.org/10.1016/j.foodchem.2008.03.021

Banji OJ, Banji D, Soumya N, Chilipi KK, Kalpana CH, Kranthi Kumar CH, Annamalai AR. 2014. Combination of carvacrol with methotrexate suppresses Complete Freund's Adjuvant induced synovial inflammation with reduced hepatotoxicity in rats. European J. Pharmacol. 15, 91-98. http://dx.doi.org/10.1016/j.ejphar.2013.12.009

Batista AG, Ferrari AS, da Cunha DC, da Silva JK, Cazarin CB, Correa LC, Prado MA, Carvalho-Silva LB, Esteves EA, Marostica Junior MR. 2016. Polyphenols, antioxidants, and antimutagenic effects of Copaifera langsdorffii fruit. Food Chem. 15, 1153-1159. http://dx.doi.org/10.1016/j. foodchem.2015.11.093

Glew RH, Glew RS, Chuang LT, Huang YS, Millson M, Constans D, Vanderjagt DJ. 2006. Amino acid, mineral and fatty acid content of pumpkin seeds (Cucurbita spp) and Cyperus esculentus nuts in the Republic of Niger. Plant Foods Human Nutrit. 61, 51-56. http://dx.doi.org/10.1007/ s11130-006-0010-Z
Goldring SR. 2000. The final pathogenetic steps in focal bone erosions in rheumatoid arthritis. Annals Rheumatic Diseases 59, 72-74.

Gupta M, Sasmal S, Mukherjee A. 2014. Therapeutic Effects of Acetone Extract of Saraca asoca Seeds on Rats with Adjuvant-Induced Arthritis via Attenuating Inflammatory Responses. ISRN Rheumatology. http://dx.doi. org/10.1155/2014/959687

Hart DJ, Scott KJ.1995. Development and evaluation of an HPLC method for the analysis of carotenoids in foods, and the measurement of the carotenoid content of vegetables and fruits commonly consumed in the UK. Food Chem. 54, 101-111. http://dx.doi.org/10.1016/0308-8146(95)92669-b

Hemshekhar M, Thushara RM, Jnaneshwari S, Devaraja S, Kemparaju K, Girish KS. 2013. Attenuation of adjuvantinduced arthritis by dietary sesamol via modulation of inflammatory mediators, extracellular matrix degrading enzymes and antioxidant status. European J. Nutrit. 52, 1787-1799. http://dx.doi.org/10.1007/s00394-012-0482-6

Kaufmann J, Kielstein V, Kilian S, Stein G, Hein G. 2003. Relation between body mass index and radiological progression in patients with rheumatoid arthritis. J. Rheumatol. 30, $2350-2355$

Kawase A, Norikane S, Okada A, Adachi M, Kato Y, Iwaki M. 2014. Distinct alterations in ATP-binding cassette transporter expression in liver, kidney, small intestine, and brain in adjuvant-induced arthritic rats. J. Pharmaceutical Sci. 103, 2556-2564. http://dx.doi.org/10.1002/jps.24043

Kelmer-Bracht AM, Santos CP, Ishii-Iwamoto EL, BroettoBiazon AC, Bracht A. 2003. Kinetic properties of the glucose 6-phosphatase of the liver from arthritic rats. Biochim. Biophys. Acta 20, 50-56. http://dx.doi.org/10.1016/ s0925-4439(03)00041-3

Knight JA. 2000. Review: Free radicals, antioxidants, and the immune system. Annals Clinical Lab. Sci. 30, 145-158.

Koracevic D, Koracevic G, Djordjevic V, Andrejevic S, Cosic V. 2001. Method for the measurement of antioxidant activity in human fluids. J. Clinic. Pathol. 54, 356-361. http:// dx.doi.org/10.1136/jcp.54.5.356

Montserrat-de la Paz S, García-Giménez MD, Ángel-Martín M, Marín-Aguilar F, Fernández-Arche A. 2013. Dietary supplementation evening primrose oil improve symptoms of fibromyalgia syndrome. J. Functional Foods 5, 1279-1287. http://dx.doi.org/10.1016/j.jff.2013.04.012

Perandones CE, Illera VA, Peckham D, Stunz LL, Ashman RF. 1993. Regulation of apoptosis in vitro in mature murine spleen T cells. J. Immunol. (Baltimore, Md:1950) 1, 3521-3529

Prakash D, Gupta KR. 2009. Antioxidant phytochemicals of Nutraceutical Importance. Open Nutraceutic. J. 2, 20-35. http://dx.doi.org/10.2174/1876396000902010020

Rauscher R, Edenharder R, Platt KL. 1998. In vitro antimutagenic and in vivo anticlastogenic effects of carotenoids and solvent extracts from fruits and vegetables rich in carotenoids. Mutation Res. 16, 129-142. http://dx.doi. org/10.1016/s1383-5718(98)00017-5

Rosillo MA, Sánchez-Hidalgo M, Sánchez-Fidalgo S, Aparicio-Soto M, Villegas I, Alarcon-de-la-Lastra C. 2016. Dietary extra-virgin olive oil prevents inflammatory response and cartilage matrix degradation in murine collagen-induced arthritis. Eur. J. Nutr. 55, 315-325. http:// dx.doi.org/10.1007/s00394-015-0850-0

Satoh K. 1978. Serum lipid peroxide in cerebrovascular disorders determined by a new colorimetric method. Clin. Chim. Acta 15, 37-43. http://dx doi.org/10.1016/0009-8981(78)90081-5

Singh GB, Singh S, Bani S, Gupta BD, Banerjee SK. 1992. Anti-inflammatory activity of oleanolic acid in rats and mice. J. Pharmacy Pharmacol. 44, 456-458. http://dx.doi. org/10.1111/j.2042-7158.1992.tb03646.x

Singleton VL, Rossi JA. 1965. Colorimetry of total phenolics with phosphomolybdic-phosphotungstic acid reagents. Am. J. Enol. Vitic. 16, 144-158.

Sonis ST. 2002. The biologic role for nuclear factorkappaB in disease and its potential involvement in mucosal injury associated with anti-neoplastic therapy. Crit. Rev. Oral Biol. M. 13, 380-389. http://dx.doi. org/10.1177/154411130201300502 
Stepaniak JA, Gould KE, Sun D, Swanborg RH. 1995. A comparative study of experimental autoimmune encephalomyelitis in Lewis and DA rats. J. Immunol. (Baltimore, Md :1950) 1, 2762-2769

Tsaknis J, Lalas S, Lazos ES. 1997. Characterization of crude and purified pumpkin seed oil. Grasas Aceites 48, 267-272. http://dx.doi.org/10.3989/gya.1997.v48. i5.802

Veronezi CM, Jorge N. 2012. Bioactive compounds in lipid fractions of pumpkin (Cucurbita sp) seeds for use in food. J. Food Sci.77, 653-657.http://dx.doi.org/10.1111/j.1750-3841.2012. 02736.x

Westergren A. 1921. Studies of the suspension stability of the blood in pulmonary tuberculosis. Acta Medica Scandin. 54, 247-245. http://dx.doi.org/10.1111/j.0954-6820.1921. tb15179.x
Wyllie AH, Kerr JF, Currie AR. 1980. Cell death: the significance of apoptosis. Int. Rev. Cytol. 68, 251-306. http:// dx.doi.org/10.1016/s0074-7696(08)62312-8

Wyrobek AJ, Bruce WR. in Hallaender A, De Serres FJ (eds.). 1978. The Induction of Sperm-shape Abnormalities in Mice and Humans, in Chemical Mutagens: Principles and Methods for Their Detection 5, 257-285.

Yosida TH, Amano K. 1965. Autosomal polymorphism in laboratory bred and wild Norway rats, Rattus norvegicus, found in Misima. Chromosoma 28, 658-667. http://dx.doi. org/10.1007/bf00285115

Zhang CF, Zhang SL, He X, Yang XL, Wu HT, Lin BQ, Jiang CP, Wang J, Yu CH, Yang ZL, et al., 2014. Antioxidant effects of Genkwa flos flavonoids on Freunds adjuvantinduced rheumatoid arthritis in rats. J. Ethnopharmacol. 14, 793-800. http://dx.doi.org/10.1016/j.jep.2014.03.046 